\title{
Environmental Education
}

\section{Supporting victimized children in Iran's legislative criminal policy}

\author{
Apoio às crianças vítimas da política criminal legislativa do Irã \\ Seyyed Sajjad Kazemi' ${ }^{10}$, Neda Sobhani"i(i) \\ ' Malayer University, Malayer, Iran \\ " Hamadan Branch, Islamic Azad University, Hamadan, Iran
}

\begin{abstract}
In today's society, children have a special place and it is no longer the case that the child is considered a family property rather, the child is an individual with his or her own personality and social status and the rights that society has for him / her. But what matters is whether the rights in our society are sufficient for children and just by telling them can it stabilize the child's position within society and save him from any attack? What should be accepted without question is that the answer is no. Because children need special rights and special protections because of their age and physical and intellectual weakness and if there is no executive guarantee to protect them, of course, not only will these rights not be respected, but they will also be violated and children who are more vulnerable than others suffer a lot. What this research specifically focuses on, a comprehensive review of child and adolescent protection law whereas, in accordance with the international obligations our country has committed to and adhered to in compliance with the convention on the rights of the child in 2000, it was approved by the Islamic Consultative Assembly in 2003. In fact, the author's attempt has been to under the pretext of reviewing and evaluating the aforementioned law, evading the existing penal regulations regarding the protection of children and adolescents in the Iranian penal system and thereby evaluate the weaknesses of the aforementioned laws and thus help the legislator to develop and enforce laws protecting certain vulnerable groups such as children.
\end{abstract}

Keywords: Differential criminal policy; Children: Child abuse: Victimization

\section{RESUMO}

Na sociedade de hoje, as crianças têm um lugar especial e não é mais o caso de a criança ser considerada uma propriedade da família; ela é um indivíduo com sua própria personalidade e status social e com os direitos que a sociedade tem para ela. . Mas o que importa é se os direitos em nossa sociedade são suficientes para as crianças e apenas dizendo a elas que pode estabilizar a posição da criança na sociedade e salvá-la de qualquer ataque? O que deve ser aceito sem questionar é que a resposta é não. 
Como as crianças precisam de direitos especiais e proteções especiais por causa de sua idade e fraqueza física e intelectual e, se não houver garantia executiva para protegê-las, é claro, não apenas esses direitos não serão respeitados, mas também serão violados e crianças que são mais vulneráveis do que outros sofrem muito. Em que esta pesquisa se concentra especificamente, uma análise abrangente das leis de proteção à criança e ao adolescente, considerando que, de acordo com as obrigações internacionais que nosso país se comprometeu e cumpriu em conformidade com a convenção sobre os direitos da criança em 2000, foi aprovada pela Assembléia Consultiva Islâmica em 2003. De fato, a tentativa do autor tem sido sob o pretexto de revisar e avaliar a lei acima mencionada, esquivando-se dos regulamentos penais existentes sobre a proteção de crianças e adolescentes no sistema penal iraniano e, assim, avaliar as fraquezas de as leis acima mencionadas e, assim, ajudam o legislador a desenvolver e fazer cumprir leis que protegem certos grupos vulneráveis, como crianças.

Palavras-chave: Política criminal diferencial; Crianças; Abuso infantil; Vitimização

\section{INTRODUCTION}

The penal law of children, the criterion of which is the age of infancy (childhood or adolescence), does not have much of a background in legal systems, The penal law of children, the criterion of which is the age of infancy (childhood or adolescence), does not have much of a background in legal systems, its appeal - as one of the branches of technical or special criminal law - in the West should be sought in the 'proof' school in the early years of the twentieth century (ABBAS ABADI MILLS, 2018, PP 90). From then on, the child was regarded as a complete human being with an independent personality, psyche, and body and thus more susceptible to delinquency. With the end of World War II and the emergence of crime-response and sociology- After that - the process of criminal prosecution of children has accelerated. In the first approach of this discipline - known as scientific or primitive forensic science - the classification of victims into various aspects has attracted the attention of scientists and criminologists. The main criteria of these classes were the vulnerability of crime victims. Accordingly, children and adult offenders were separated on the basis of age pathological criteria. As such, child protection as one of the vulnerable categories of victims of crime has entered the realm of criminal law and criminology.

It can be argued that the most important children affected by the Iranian society are the working children, street children, victims of harassment, trafficking and pornography. In fact, these children are victims of social, economic, cultural, legal and 
judicial conditions of society. Many of these children are never seen and may be referred to as (invisible children) (MOHAMMADI ARANI, 2015, P. 2). These children lack family support and in cases where they are violated, they are not protected by the criminal system because of their particular situation. Therefore, it seems that children, as the most vulnerable part of society, should receive the attention of legislators and researchers in the fields of criminology and psychology. In other words, the best way to do this is to raise awareness and raise the culture of the community in this area and to enact protection laws in line with international standards (NAGHATI, 2018, P 65). Child victimization is an issue that has not received much attention in our society and consequently, there is no protection law or a clear discriminatory criminal policy on it and so it requires special legal and social support and action. Child victimization will have devastating consequences for the future of society because today's victimized children are the potential criminals of tomorrow's society (AFROOZ, 2015, P 68). Perhaps the most important reason for the current situation of children in our country is the lack of adequate protection laws and the lack of specific criminal policy in this area.

In this article, we will try to explain the concept of child victimization and its causes after giving some general information Protection of Children and Adolescents Adopted in December 2002 as the Most Important Child Protection Act is investigated and discuss its strengths and weaknesses, and in particular the extent to which they meet international standards, in particular the Convention on the Rights of the Child. It should be noted that since a new bill is in place for child protection and additional safeguards to be prepared, formulated and approved, the ultimate goal of this study is to identify the weaknesses of the above-mentioned law in order to help the legislator to pass more comprehensive laws in this field.

\subsection{Child victimization and the need to support them}

Criminal law since the birth of the ancient world has played a prominent role in the criminal process to this day. From the Hittite laws (AKBARI, 2010, P. 122) and the 
Hammurabi law to the laws of the ancient world empires such as Iran, Rome and Greece and from the great divine religions, such as the Shari'a of Moses and Islam, to the works and writings of the Church members in the Middle Ages, there has been some talk about the role of the victims in the perpetration of criminal offenses and the promotion of criminal proceedings and the necessity of compensation for them, however, this attention has been unintentional, tacit, and in many cases unconscious. A review of the history of criminal law developments in the world reveals numerous and varied examples of child victimization. For example, in the Arabian Peninsula in our pre-Islamic era, children are considered as the property of parents and children have been subjected to severe harassment during this period, so long as they have buried their daughters alive or in Europe in the Medieval, children have long had no special place in society.

When referring to the term child offenses, it means a child who, under the laws and regulations, is the subject of the offense, which is, a crime was committed against him, which according to the criminal law, must be a minor offense. Now the question is, what does the child support here mean?

Regardless of the wide-ranging discussions in our jurisprudence and legal record, to answer this question, one can refer to Article 1 of the Child and Youth Protection Act, which covers all persons who have not reached 18 years of age. In fact, it is the only regulation that sets the age of 18 as a criterion for legal and criminal protections for children.

There are many factors involved in child victimization. But in summary, family, school, workplace, living environment, mass media and some other cultural factors are the most important factors affecting child victimization (ABBACHI, 2001, P. 25). That is why, in the International Convention on the Rights of the Child, most emphasis has been put on preventing child abuse, and has suggested a number of measures to make these institutions more effective and effective.

Child support can take many forms. This support can range from a wide range of ethical approaches to criminal prosecution; there are many forms of support that can 
be broadly divided into criminal and non-criminal support. Obviously, criminal protection should be the last resort and support and if other remedies are inadequate and inadequate, resorting to criminal enforcement guarantees can provide effective support for children at risk (CLARKSON, 1992, P. 224).

But the questionable question is what essentially the basis of a victim protection plan is? And in other words, why should "children" is protected as a group of people?

In response to this question, various views and foundations, such as the failure of governments to support victims or philosophical or value foundations, have been cited by some scholars (ABROUSHAN, 2018, P. 29).

But perhaps the most important basis for this support is its very important and effective role in reducing delinquency.

Accordingly, even if the victim is found guilty of his or her victimization, it is necessary and reasonable to support him / her: because, on the other hand, this protection and damages make him immune from the repeated victimization of his first weakness, isolation, helplessness, and victimization. On the other hand, it prevents individual retaliation and the spread of delinquency (ABROUSHAN, 2018, P. 29).

Now it seems that the first and foremost strata that need support among the different types of crime victims are children. There is no doubt that children need more support than other vulnerable people. In addition to the protections that can be exercised through various civil society institutions, what are most noticeable are the mechanisms of substantive criminal law for special protection of children. Thus, criminal law using its own mechanisms, that is, the criminalization of some of the behaviors and the intensification of the punishment of criminals who choose children as their victims, it advocates discriminatory criminal support for children in order to reduce their vulnerability (ZEINALI, 2013, P. 60). The authors of the child and adolescent protection plan have also been ignorant of and influenced by the facts and findings of criminology and forensic science in support of its adoption, we will discuss this law from different angles. 


\subsection{Subject of the Adoption of the Law on Protection of Children and Adolescents Adopted in 2003}

With the passage of the law, there were signs of adopting a "differential criminal policy" in dealing with child crimes in Iranian criminal law. A law, which unlike its general title criminalizes child protection by criminalizing certain behaviors. By looking at the issues raised during the passage of this law, it becomes clear that: In passing this law, the legislator has been most influenced by civil society, international commitments, in particular the Convention on the Rights of the Child, the facts and findings of psychology, criminology and victimization. A law that first introduced the term "child abuse" into Iranian criminal law literature with the first founding of "Criminal Rights of the Victimized Children" in Iran and the age of the victim was determined to be eighteen years in line with the scientific findings and the Convention on the Rights of the Child. Acts of criminality such as any harm, harassment, psychological and physical torture of children, deliberate neglect of the child's mental and physical health, prohibition of their education, any purchase, sale, exploitation and use of children to commit wrongdoing, one of the innovations of the law mentioned above (ZEINALI, 2013, P. 62). A law that promises "child abuse" and criminalization in order to force reporting of child abuse cases promises the formation of a special child abuse justice system. Therefore, child and adolescent protection law can be considered a step forward in protecting children and adolescents from psychological and physical violence.

In 1959, the Declaration of the Rights of the Child was adopted by the UN General Assembly In fact; it laid the foundation for the Convention on the Rights of the Child. The draft Convention on the Rights of the Child, which was unanimously ratified by the Polish initiative in 1989, consists of an introduction and 54 articles. Of these articles, 41 are related to child rights and 13 are related to how they are implemented in each country. So far, 191 countries out of 193 have joined it, and only two countries, the United States and Somalia, have yet to accede to the convention. 
The main purpose of this Convention is to create a better life for children and to strive for their harmonious and balanced development in the essentials of physical, mental, emotional, mental and social development and to achieve this goal, four aspects of growth, survival; support and participation have been taken into consideration (POURGHAHREMANI, 2014, P. 6). The Islamic Republic of Iran is one of the countries that signed the Convention on the Rights of the Child in 1990 and ratified it in March 1993. Iran has, of course, accepted this Convention by exercising the right to: "It has the right to make any provision which is contrary to Islamic law and reserves the right to declare such condition upon its approval ....." and the Islamic Consultative Assembly also adopted it with the general restriction of not complying with Islamic law and domestic law. As some writers have emphasized, in fact, by joining the Convention, the Iranian Government does not seek to adapt and amend its laws, rather, it enforces its own rules and in the future it will enact and enforce laws that it deems appropriate and anyway, wherever the provisions of the Convention are found to be inconsistent with existing domestic or subsequent laws, these provisions are not required by the Iranian Government (BEIGI, 2015, P. 43) and that is the subject of protest by many countries and they find this general requirement unacceptable and incompatible with the Convention (MEHRPOUR, 1998, P. 129).

In line with this Convention and Iran's accession to it, the Islamic Consultative Assembly in 2002 adopted a Child and Youth Protection Act, which contains nine articles. Under the law, individuals under the age of 18 have all been supported by the law, it is also forbidden to harass children and adolescents who endanger their physical and mental health. Pursuant to Article 3 of this Law, any purchase, sale, exploitation and exploitation of children for the purpose of committing unlawful acts, such as trafficking, prohibition, and commission in addition to compensation shall be punishable by penalties and according to Article 4, any physical, mental, physical, mental, or physical abuse of children and their deliberate neglect of their physical and mental health and their education is prohibited. Incidentally, child abuse is a public crime and does not require a private complaint. Persons, institutions and centers that are responsible for 
the custody and custody of children are required to notify the competent judicial authorities as soon as the child is found. As can be seen, most of the articles of the Convention on the Rights of the Child are set out in this law and this demonstrates the legislator's sensitivity to the case, which is commendable. In the following, the most important criticisms of this law are discussed.

\subsection{The most important criticisms of the Child and Youth Protection Act}

Perhaps the law was adopted more for propaganda or political incentives and so despite some innovations, acceleration and many shortcomings are visible. Somehow it has made some of the provisions of this law as a neutral and ineffective law. This is much more evident in view of the deliberations of the Islamic Consultative Assembly and the views of the Guardian Council when it was adopted.

However, under this law, child abuse is considered a public offense and therefore does not require a private complaint to be prosecuted, but problems, such as a lack of a comprehensive, detailed and clear definition of child abuse and justification, are some of the crimes against children and can be handled under specific laws, the amendment of the aforementioned law has been put on the agenda of the judiciary.

Perhaps the most important criticism of the law is that it does not include cases where parents and careers attempt to discipline and punish a child. This caused a great deal of debate between the Islamic Consultative Assembly and the Guardian Council. Although lawmakers have adopted a proper differential policy to protect children but despite materials such as Article 59 and Article 1179, the Civil Code has paved the way for assault on children (HABIBZADEH AND MOGHADASI, 2016, P. 66). According to Article 1179 of the Civil Code, the right to discipline is restricted to parents only, but under Paragraph 1 of Article 59 of the Islamic Penal Code, in addition to parents, legal guardians and guardians of children are also entitled to discipline. However, this article sets out two intrinsic measures of intent to discipline and an external criterion at a standard level to distinguish whether or not to discipline children (KATOOZIAN, 1999, P. 723), but it has caused many parents and guardians to abuse children. Not only has this 
provision victimized children on the pretext of discipline, but some have even gone so far as to place teachers and teachers in the hands of parents and careers, giving them the right to discipline and punish children. (MOHSENI, 1997, P. 67) this is in breach of the Criminal Code and Article 77 of the Executive Code of Schools. With the passage of the Child and Adolescent Protection Act, the hope of the legal community to address child abuse, especially by parents who used Article 59 exemptions, increased. But repeated amendments to the law also diminished hope. In the original design, child abuse could be committed by anyone; however, in the wake of numerous amendments by the Islamic Consultative Assembly to the opinion of the Guardian Council, parents were excluded from the law under Article 7. However, based on research, unfortunately, about $75 \%$ of child abuse cases are committed by parents and guardians of children (ABROUSHAN, 2018, P. 11).

What was the main purpose of the designers of this law was completely eliminated by Article 7. According to available statistics, most cases of child abuse are committed by parents who are excused from punishment (HABIBZADEH AND MOGHADASI, 2016., P. 67). Thus, with the passage of this article, the enforcement of the Child and Adolescent Protection Act was greatly restricted, and the designers failed to achieve their primary goal, which was to combat "child abuse within the family." In the following, the most important disadvantages of this legislation are analyzed.

\subsection{Incomprehensiveness Law}

It seems that this law, contrary to the title of "Child and adolescent protection law", did not fully address his rights and that the choice of the title followed the propaganda aspect. However, in addition to criminal support for children and adolescents, it is imperative that other legal protections be required for children and adolescents to meet their needs. But, contrary to the title, the law addresses child abuse and it ignores one aspect of it, namely the discriminatory criminal protection of children victimized in the light of the particular criminalization of certain behaviors, and of other 
mechanisms in substantive criminal law, namely the intensification of the punishment of criminals who commit crimes. Not much is visible about the specific legal protections for abused children in the criminal process. If necessary up to special legal protections for abused children to extend to other stages of the criminal process, including the prosecution process, prosecution, investigation, verdict and enforcement, and even after the due process (ZEINALI, 2003, 2, P. 22).

\subsection{Remove parent from the task of reporting child abuse}

One of the objections of the Council of Guardians to the first resolution of the Islamic Consultative Assembly was the requirement of Article 6 (compulsory reporting of child abuse by all persons and institutions responsible for their upbringing and education) which also includes parents of children who have harmed their child as a child and the Islamic Consultative Assembly, with the approval of Article 7 above, moved in the direction of the Guardian Council and removed the parents from Article 6. Since the closest person to a child is in his or her parent's community, stipulating duties for the child's parents and placing a guarantee of non-compliance with the child could greatly reduce child victimization, something we are very much confronted with today and a large percentage of crimes against children remain hidden from the perspective of law enforcement and law enforcement agencies.

\subsection{Not paying attention to civil society organizations}

The legislator was required by law to: In line with a participatory criminal policy and the need for civil society participation in criminal policy and the fight against child abuse, it also addressed NGOs and NGOs active in the field of child rights and in addition to the Welfare Organization, it provided for them tasks and powers just like other countries (Such as giving them authority to track and report child abuse cases). 


\subsection{Ineffectiveness of the legislator from International Conventions on the Rights of the Child}

In international agreements such as the Convention on the Rights of the Child and the Convention on the Rights of the Child, adopted worldwide in support of children's rights, much support is anticipated the legislator should have considered and included them in the adoption of the Protection of Children and Adolescents Act. These include the following:

$\checkmark \quad$ The right to freedom of opinion, including; freedom to seek, receives and impart information

$\checkmark \quad$ No interference with children's privacy or family affairs and their correspondence

$\checkmark \quad$ The rights of children with disabilities should be recognized and special care should be provided for them.

$\checkmark \quad$ Need to insure children

$\checkmark \quad$ Providing leisure and playground equipment suitable for children and...

\subsection{Non-assignment of the right to file a complaint to the Welfare Organization}

One of the cases provided for in Article 5 note was: "In addition to the relevant judicial authorities, the Welfare Organization also has the right to appeal to the courts of justice." That the Guardian Council has found this note contrary to Articles 57 and 156 of the Constitution and it has also stated that because the right to welfare requires that it be able to consent, so this is contrary to religious law and is contrary to Articles 57 and 156 of the Constitution. In order to eliminate the objections of the Council of Guardians, the note was also removed by members of the commission, and delegates voted in favor of the removal. One of the reasons the bidders had a plan to bring this note was that the Welfare Organization, as the only institution most concerned with the problems and problems of children affected, delivering such a right can therefore be effective in following up child abuse and child protection. The objections of the 
Guardian Council were that because the assignment of such a right also required the consent of the organization, it was against the constitution and the Shari'a. Unfortunately, the MPs, instead of eliminating this objection, "getting the right to consent" removed the whole note.

\subsection{Ignoring the necessity of establishing a child-specific criminal justice system}

Just as the attitude toward child labor in the criminal justice system is different from that of adults, victimized children also need a differentiated view of the criminal process and this is due to the specific mental and psychological state of the child (ABBASABADI, 2001, P. 210). Therefore, it is necessary for the legislator to facilitate the process of informing the criminal justice system of child abuse (child abuse) by prescribing mechanisms in the first stage, in this way, children who have been victimized will enter the criminal process and the proceeding. In the later stages, with specific rules provided, at other stages of the proceedings, not only will children be reexposed within the criminal process, rather, by accelerating differential investigations, protections and legal aid, and repairing the material and psychological damages inflicted on these particular victims, formulate and set up a system for the (special) criminal justice system for children (ZEINALI, 2003, P. 22). But despite this, the discriminatory support for children who have been victimized in the criminal process, both before and after, has been neglected at the legislative level and even at the level of research and studies in the field of child criminal law.

\subsection{Supporting Victimized Children in trial process}

As summarized in previous discussions, various principles have been put forward to support child victims. From philosophical and ideological foundations to issues such as the value basis, the failure of governments, non-judicial settlement, and the reduction of child abuse by various experts. But as mentioned earlier, it seems that the most important basis for a child protection victimization plan, aside from its value and ideological dimensions, it has a very effective and valuable role in reducing child abuse. 
According to this view, even if the victim's child is involved in his or her victimization, it is reasonable to support him / her. Because, on the other hand, this protection and damages make him immune from the frequent victimization that results from his childhood, weakness, isolation, helplessness and victimization and, on the other hand, it prevents children from being exposed to criminality and their perpetration. Therefore, protecting victims of child abuse, in addition to its value dimensions, has an effective role to play in preventing crime, because it both prevents their secondary victimization and prevents adult offspring from becoming a criminal. Considering the basics of victim protection plan, it is attempted to present the most important practical child protection strategies at different stages, from the time of the crime to the end of the trial. Support for child victimization is generally in three stages:

1. Supporting Victimized Children Immediately after the crime

The victim is a weak human being who, at an early age, has made him a vulnerable human being and thus a potential victim. It is natural that such a child has many needs, so what's important is identifying needs and providing them based on rational priorities. It seems that the first need for children, who have been victims of crime against them, is the effort to alleviate and alleviate their physical and psychological harm. The most important of these efforts can be seen as medical assistance and the relief of mental illness. The most important of these efforts can be seen as medical assistance and the relief of mental illness. Providing emergency treatment for pediatric needy children, it takes precedence over their other needs. High human principles require that the basic needs of a child be treated, even if he or she is guilty of a crime, as soon as possible. Also, the mental state of the offspring affected by the crime is unbalanced and often depressed, anxious or upset. These situations vary according to the type of victimization they are seeing (BEIGI, 2015, P. 31). For example, because children of victims of moral crime have become spiritually defeated and typically suffer severe isolation and sadness, they may find themselves treating their pain as suicidal or in hiding from society. On the contrary, children who are victims of crimes such as abuses, slander or slander often seek to defend themselves and even 
take revenge after puberty. The purpose of these protections is to prevent them from becoming adults. In most cases, the absence of such care, in addition to their revisitation, is also effective in committing crime on their part.

2. Supporting Victimized Children in trial step

In principle, the victim is a human child whose rights have been violated by adults. Re-enforcing such a right and defending it often requires litigation and because most of the time the crime is committed against them by their parents and other legal guardians, they refuse to go to court for their own benefit and thus play an effective role in the recurrence of child victimization. Coming to the effect of not affecting the statements of the children of the victim, as a result of the fact that they are children and talk about emotions, aggravates the problem. Therefore, support for victimized children has several effects at the hearing that is for the sake of brevity dimensions such as: understanding the rights of children who have been victimized and trusting that their statements and complaints will be followed up or the use of a guardian to bring a lawsuit, especially in cases where the parents or other legal guardians have committed a crime against them.

3. Supporting Victimized Children At the step of providing losses

Victimized children are of the "spiritual" type, but in many cases victims of direct and indirect child abuse suffer material damages. Losses to victimized children include a series of damages that they inflict on them when their crime is committed until their effects are partially resolved. Naturally, the costs of medical treatment will be added to the damage directly caused by the crime that the first and foremost person to respect for compensation is the adult offender. Of course, in some cases, the adult is not identified as a perpetrator, but the child's peers commit the crime or, in some cases, the adult offender is hiding or hiding and is not allowed to access him long after the crime has occurred or even if the criminal is arrested, he or she is financially incapable of compensation. In these cases, the most important alternative sources are government, charity and insurance, these alternatives have been suggested by international conventions to compensate for child harm (BASERI, 2019, 128). In our 
country, unfortunately, these alternative sources have been considered in scattered formats. It is therefore imperative that their operation be organized and organized.

\section{CONCLUSION}

Children are referred to as "potentially vulnerable people" or "people with a prior victimization" or "potential victims" because of their physically, mentally, and socially vulnerable status and position. Because of this, they are more vulnerable than adults lawmakers have made special differential protections to prevent them from being victimized, both within the family and in the community. What our legislator seems to have largely overlooked. There is no doubt that such vulnerable victim's need more help and support. In addition to the support that can be exercised through civil society and civil society organizations, most notable are the mechanisms in place for substantive criminal law for special protection of children. Thus, criminal law uses its own mechanisms, namely the specific criminalization mechanism for certain behaviors and the intensification of the punishment of criminals who select children as their victims, it discriminates against children in order to reduce their vulnerability. It seems that the Child and Adolescent Protection Act was also adopted for this purpose, however, the mention of some of the provisions and provisions of this regulation made the above-mentioned law completely obsolete from its original purposes and unable to fulfill them. Of course, this law has created innovations in the area of children's rights, including: Incorporate the term child abuse in our legal literature, or set the age of eighteen for support as well as making reporting tasks compulsory for community members and to introduce some new criminals in this field that are all very commendable but there are a number of criticisms to the law that were raised during the debate. Examples are the exclusion of parents from the rule of law, the incompatibility of the law, disregard for the Convention, and so on. But in general, the law is a major innovation, both in the process of drafting it and in the content of its drafting in parliament and in terms of its content, in general in Iranian penal law and in 
the criminal law of children in particular. Of course, the legislator should take the criticism into consideration when reviewing the law and correct the violations.

\section{REFERENCES}

ABBASABADI MILLS, MARZIEH. Comparative Study of the Convention on the Rights of the Child with the Convention on the Rights of the Child in Islam, MSc Thesis, University of Tehran, 2018.

ABROUSHAN, HOOSHANG. Child Abuse and the Convention on the Rights of the Child, Publication of Thoughts, First Edition, 2018.

AFROOZ, G. Reopening a Case: Why He Was Dead ?, Tarbiat Publishing, First Edition, 2015.

AKBARI, F. An Introduction to Laws on Children, Law Journal of Justice, No. 31.Pp, 115-135, 2018.

BASERI, A.A. Juvenile Justice Policy, Khorsandi Publications, First Edition, 2019.

BEIGI, J. Child Abuse in Iranian Law, Publication of the Case, First Edition, 2015.

CLARKSON, C. Analysis of the Principles of Criminal Law, translated by Hossein Mirmohammad Sadeghi, Journal of Academic Jihad. PP 215-234, 1992.

HABIBZADEH, M., JAFAR-ROOYIN, T., MOHAMMAD, B. An Income on Criminal Protection of Victimized Children in Iranian Law, Legal Journal, Volume 2, Number 1.pp 50-71, 2016.

KATOOZIAN, N. Civil Law in the Present Legal Order, Justice Publishing, Third Edition, 1999. MEHRPOUR, H. International Human Rights System, Information Publication, First Edition, 1998.

MOHAMMADI ARANI, KH. Child Protection in Iranian Criminal Justice Policy, MSc Thesis, Mofid University of Qom. PP 1-19, 2015.

MOHSENI, M. Public Penal Law, vol. 3, knowledge treasure publishing, first edition, 1997.

NAGHATI, A. Criminal Protection Policy for Victims, Journal of Qom Higher Education Complex, No. 4. PP 58-73, 2018.

POURGHAHREMANI, B. A Look at the Convention on the Rights of the Child, Rogue Andisheh Journal, No. 38.pp 1-22, 2014.

ZEINALI, H. The Innovations of the Law on Protection of Children and Youth and its Challenges, Social Welfare Quarterly, No. 7.pp56-73, 2013. 


\section{AUTHORSHIP CONTRIBUTIONS}

\section{1- Seyyed Sajjad Kazemi}

Assistant Professor

https://orcid.org/0000-0002-9943-3150 | E-mail: Sskazemi92@Malayeru.ac.ir

Contribuition: Supervision, Project administration, Writing - review \& editing, Investigation, Visualization, Methodology, Software

\section{2- Neda Sobhani:}

Assistant Professor

https://orcid.org/0000-0003-4025-4366 | -mail: nedasobhani@gmail.com

Contribuition: Validation, Data curation, Formal Writing - original draft, Analysis, Funding acquisition, Resources, Conceptualization

\section{HOW TO QUOTE THIS ARTICLE}

KAZENI, S. S; SOBHANI, N. Supporting victimized children in Iran's legislative criminal policy. Revista de gestão, educação e tecnologia ambiental, Santa Maria, v.25, e3, 2021. Available from: https://doi.org/10.5902/2236117063800. Accessed: Month Abbreviated. Day, year. 